\title{
MOTIV OG KONTEKST
}

Emnet for denne artikel er motivets egenskaber og funktioner i forhold til den litterære teksts kontekst, som jeg her forstår bredt som de såvel materielle som ideologiske historiske, sociale og kulturelle omstændigheder for teksten, som den optager på specifikke måder. En tendens i aktuel litteraturhistoriografi er en tiltagende skepsis over for kontekstualisme, der tager udgangspunkt i den måde, som tilgangen forhindrer kritikerens engagement i teksten. Over for denne skepsis forsvarer jeg kontekstualisme - men forstået som en praksis, der ikke blot kan gøre litterære tekster mere forståelige for os, men også mere fremmedartede. Artiklens tese er, at det snarere er ved at orientere kontekstualismen mod litterære motiver end mod tematikker, at vi kan italesætte litteraturens historiske fremmedartethed. Denne tese afprøver jeg gennem en analyse af et hidtil ubelyst motiv i dansk litteratur, nemlig bakterier.

\section{EN AKTUEL SKEPSIS OVER FOR KONTEKSTUALISME}

Forholdet mellem den litterære tekst og dens kontekst er et centralt spørgsmål inden for litteraturhistoriografien. Gennem det 20. århundrede har indflydelsesrige litteraturvidenskabelige skoler som den russiske forma- 
lisme, nykritikken, strukturalismen og dekonstruktionen advokeret for immanente tilgange til litteraturen med afsæt i en kritik af kontekstualisme som praksis. Disse tilgange orienterer sig mod litteraturens "litteraritet", den specifikke form for sprogbrug, der adskiller litteraturen fra andre diskursformer, som de først og fremmest finder i litteraturens form. Denne identifikation af litteraritet med form er fundamentet for forestillingen om den autonome tekst, det vil sige tekstens iboende modstand mod at blive reduceret til dens kontekstuelle omstændigheder. ${ }^{1}$

En sammenlignelig skepsis over for kontekstualisme synes at tage form i dag. Jeg vil diskutere en konkret manifestation af den, nemlig i tidsskriftet New Literary Historys temanummer om kontekst (42:4) fra 2011. I sin introduktion til nummeret indrømmer redaktøren Herbert F. Tucker først, at "den hævdvundne kraft, som kontekstualisme har udøvet over den måde, vi forstår historie og kultur på, har leveret en vis metodisk klarhed og et disciplinært fokus", men erklærer derefter, at "disse gevinster har haft store intellektuelle omkostninger" (Tucker vii). Sådanne omkostninger diskuterer bidragyderne til nummeret fra en række perspektiver, der i sig selv tyder på, at kontekstualisme ikke længere er en selvfølgelig tilgang til litteraturhistorien. Man kan identificere to overordnede tendenser i deres indsigelser. Den ene er, at kontekstualisme distancerer den litterære tekst fra læserne. Den anden, at teksterne - eller nogle tekster - udfordrer kontekstualisme ved at overskride deres kontekst.

Rita Felskis bidrag med den slagkraftige titel "Context Stinks!" følger den første tendens. Hendes modstand mod kontekstualisme har udgangspunkt i en kritisk holdning til "mistænksomhedens hermeneutik", der tildeler konteksten en forklarende autoritet i forhold til teksten. Felskis hovedpointe er, at en sådan tilgang til litteraturen indespærrer teksten i en beholder af synkrone relationer, der genererer en fornemmelse af en uoverkommelig distance mellem den og nutidige læsere. Kontekstualisme tilhører det domæne, som Way Chee Dimock benævner som "synkron historicisme", der "tillægger betydninger til en tekst ved at placere den blandt

1 Se Sestoft for en udførlig diskussion af det problematiske forhold mellem tekst og kontekst. 
begivenheder i den samme skive af tid" (Dimock 1061). Dermed negligerer tilgangen ifølge Felski "spørgsmålet om, hvorfor fortidige tekster stadig betyder noget, og hvordan de taler til os nu" (Felski 577). Den hindrer en forståelse af, hvad hun primært er interesseret i, nemlig tekstens "affektive resonans" (574).

For at begribe denne resonans har Felski brug for begreber, der kan relativere tiden, og finder dem i Bruno Latours aktør/netværk-teori. For Latour er historisk tid ikke en lineær udvikling, der efterlader en forgangen periode restløst bag sig, som den skrider fremad, men en "mangfoldighed af strømhvirvler og strømfald, tilløb og fraløb" (Felski 578), hvor objekter og forestillinger fra forskellige tidspunkter mødes i omskiftlige netværk. Hvert enkelt historisk øjeblik er i dette perspektiv en hybrid af forskellige tidsperioder. Felski forstår den litterære tekst som en ikke-menneskelig aktør i sådanne netværk, det vil sige som et element, "der forandrer en tilstand ved at gøre en forskel" (582). Tekstens affektive resonans er en agens eller handlekraft, der stammer fra dens særegne egenskaber, og som gør den i stand til at påvirke læserne.

Hun overfører denne forståelse af teksten til modsætningsforholdet mellem på den ene side forestillingen om tekstens autonomi, og på den anden, forestillingen om kontekstualismens uomgængelighed for forståelsen af teksten. Latours aktør/netværk-teori gør det ifølge Felski muligt på samme tid at fastholde opmærksomheden på tekstens særegenhed og på dens relationer til andre aktører i skiftende netværkskonstellationer: "kunstens autonomi [...] er selve årsagen til, at forbindelser etableres og opretholdes." (584) Det er undersøgelsen af disse relationer, der kan føre til en forståelse af tekstens affektive resonans.

Martin Jays artikel fra det samme nummer af New Literary History, "Historical Explanation and the Event", følger den anden tendens i bidragydernes indvendinger mod kontekstualisme, nemlig at tilgangen udfordres af nogle litterære tekster, der overskrider deres kontekst. I artiklens indledning opsummerer Jay en række sammenhængende kritikpunkter, der er blevet rejst mod kontekstualisme "som den privilegerede historiografiske metode" (Jay 559), en positionering, som han forbinder med den såkaldte Cambridge-skole i idéhistorie generelt og med Quentin Skinners arbejde specifikt. Kritikpunkterne omfatter problemet med, hvordan man 
på en vederhæftig måde kan rekonstruere en fortidig kontekst, siden den kun er tilgængelig for os i form af tekster, der selv må kontekstualiseres, problemet med at bestemme hvad de væsentligste kontekster for forståelsen af en tekst er, eftersom dette bliver mindre og mindre selvfølgeligt, jo længere tilbage i tiden man bevæger sig, og problemet med, hvordan man italesætter forholdet mellem forskellige kontekster, der måske alle er relevante for forståelsen af en tekst, men som er usammenlignelige på grund af deres indbyrdes placering på en perspektivisk skala, der strækker sig fra et individuelt til et globalt niveau. ${ }^{2}$

Som en konsekvens af disse indvendinger foreslår Jay, at man i det mindste bør skelne mellem litterære tekster, der kan blive belyst ved at indlejre dem i deres kontekster, og tekster der ikke kan. Forskellen uddyber han med henvisning til Claude Romanos forestilling om begivenheden ("l'événement"), der er etymologisk beslægtet med fremkomsten ("l'avènement") af noget nyt. Hvis man forstår en tekst som en begivenhed i denne forstand - og det er vigtigt at notere, at tilfældene ifølge Jay er "sjældne og ikke altid lette at identificere" (567) - kan den kun forstås fra en synsvinkel, der tilhører den fremtid, som teksten selv igangsætter. Som begivenhed vil teksten derfor overskride den forklaringsevne, som en kontekstualisme, der er synkront orienteret, besidder.

Den læser, der involveres i teksten som begivenhed, forvandles som følge heraf til, hvad Romano kalder en "advenant": "Hvad der sker for advenanten er eksistentielt forandrende, fordi den begivenhed, der finder sted ikke kan betragtes med ligegyldighed fra en ydre synsvinkel, han eller hun er fuldt involveret i den." (565) Med udgangspunkt i denne idé foreslår Jay som et alternativ til kontekstualisme en litteraturhistorisk tilgang, der orienterer sig mod hvad F.R. Ankersmits kalder "den sublime historiske oplevelse", en oplevelse, der på en autentisk, intim og intensiv måde involverer litteraturhistorikeren.

I sidste ende synes Felski og Jay altså at have et fælles mål, nemlig at etablere nogle praksisser, der tillader litteraturhistorikeren at engagere sig i den litterære tekst i højere grad end kontekstualisme gør det. Bag denne ambition fornemmer man konflikten mellem forestillingerne om 
den litterære teksts litteraritet og om kontekstualisme som et nødvendigt redskab til forståelsen af teksten.

\section{SKINNER OG HISTORIENS FREMMEDARTETHED}

Som nævnt i indledningen vil jeg imidlertid forsvare kontekstualisme, forstået som en historiografisk praksis, der har som formål at få litterære tekster til at fremstå som mere fremmedartede for os, det vil sige at insistere på deres historiske fremmedartethed. Det er vigtigt, tror jeg, at vi forsøger at modstå trangen til at spejle os selv og vores aktuelle stilling i fortiden. I en idéhistorisk kontekst er dette synspunkt blevet fremsat på forskellige måder af tænkere som Hans Blumenberg (med hans kritik af "samtidens absolutisme" og hans appel til eftertænksomhed i omgangen med historien), af Reinhart Koselleck (med hans hævdelse af den positive værdi af forgangne erfaringers fremmedgørelseseffekt) og af Quentin Skinner. ${ }^{3}$ Jeg vil her fokusere på Skinners formulering af den.

I essayet "Meaning and Understanding in the History of Ideas", der først blev publiceret i 1969, og siden i en bearbejdet version i 2002, retter Skinner en kritik mod en universalistisk tilgang til den politiske tænknings historie, der var dominerende i 1960'erne. Den beskæftigede sig med en kanon af klassiske tekster om emner, som opfattedes som tidløse. Skinner udpeger tre "mytologier", som denne tilgang resulterede i, og demonstrerer deres implicitte faldgruber. Både mytologierne og faldgruberne er konsekvenser af en metodologi, der udelukkende havde for øje, hvad tænkerne skrev, men som forsømte at diskutere hvad de mente, da de skrev det: "Forståelsen af enhver seriøs ytring kræver, at man begriber ikke alene betydningen med det sagte, men også den tilsigtede kraft, hvormed udsagnet ytres. Man er altså nødt til at begribe ikke blot, hvad folk siger, men også hvad de gør i og med, at de siger det." (Skinner, "Mening og forståelse i idéhistorien", 85) Til det formål gør Skinner brug af J.L. Austins talehandlingsteori. ${ }^{4}$ Som et alternativ til den universalistiske idéhistorie

3 Se Beck-Lassen for en uddybning af de former, som synspunktet om værdien af historisk fremmedartethed antager hos de tre tænkere.

4 Se Skinner 2002 for en fremstilling af hans brug af Austins teori. 
foreslår han en tilgang, der situerer teksterne i de samtidige debatter, som de deltog i. Udgangspunktet er hvad Austin benævner som forfatterens illokutionære intentioner, det vil sige de hensigter, han eller hun har med at fremsætte en ytring.

I essayets konklusion vender Skinner sig mod den værdi, som studiet af idéhistorien har. Det virker for ham som "et håbløst foretagende at forsøge at retfærdiggøre stoffet ud fra de svar, det kan give på de "tidløse problemer', som de klassiske tekster angiveligt forholder sig til." (93) Der findes ifølge Skinner ingen tidløse problemer. Enhver ytring er fremsat ved en bestemt lejlighed og adresserer en specifik problematik: "de klassiske tekster handler om deres egne og ikke vore spørgsmål" (93). De filosofiske - endda moralske - værdier, som disse tekster besidder, er ikke resultatet af de udtrykte idéers fundamentale ensartethed, men af deres variation. I et interview i tidsskriftet the art of theory fra 2011 uddyber han denne pointe: "Et ledelys har for mig altid været idéen om, at hvis du begynder med at fremmedgøre dig fra fortiden, at se den som mærkværdig, og forsøger at se på tingene på deres måde, så ville det være et forsøg på at rekonstruere svar på spørgsmål, som vi ikke længere stiller." (Skinner, "Quentin Skinner on Meaning and Method")

Udsagnet leder opmærksomheden hen på den aktuelle betydning, som studiet af idéhistorien har. Den udgør "et lager af værdier, vi ikke længere tilslutter os, og af spørgsmål, vi ikke længere stiller", skriver Skinner i essayet "Freedom and the Historian" (Skinner, "Frihedsbegrebet og historikeren.", 242), det vil sige et vidnesbyrd om de måder, som vi ikke har organiseret livet i dag på. Studiet af andre samfunds forestillinger er et uundværligt og uomgængeligt middel til at overskride de skjulte begrænsninger for vores forestillingsevne, som vi er underlagt som følge af vores egen situering i specifikke historiske omstændigheder. Det kan bevidstgøre os om, at vores opfattelse af, hvad der er selvfølgeligt, er et resultat af historiske valg, der kunne have været anderledes.

Skinners kontekstualisme er blevet mødt af en velbegrundet kritik, der ikke mindst har drejet sig om den rolle, som intentionalitet har i den. Som Jay skriver, er den smalle, intentionalitetsbaserede forståelse af kontekst, som Skinner præsenterer, uforenelig med bredere, ideologibaserede forståelser. Disse forsøger netop at bevæge sig hinsides forestillingen om 
den forandrende kraft, som bevidste intentioner besidder. Desuden påpeger Jay, at Skinner har en tendens til at behandle intentionelle ytringer som retningsbestemte, mens "én intention [i realiteten] altid griber ind i andre og handlinger altid er engagerede i andre handlinger, hvilket nemt kan lede til utilsigtede konsekvenser." (Jay 562)

Jeg mener imidlertid, at Skinners forestilling om at betragte fortiden som fremmedartet og på dens egne betingelser kan imødegå nogle af de kritikpunkter, der ofte bliver rejst mod kontekstualisme. Hvis man fokuserer på den litterære teksts historiske fremmedartethed, bidrager man selvfølgelig til at generere en fornemmelse af en uoverkommelig distance mellem fortid og nutid, som Felski skriver. Det tilskynder til en "synkron historicisme". Men som jeg har berørt, indebærer dette bestemt ikke, at "spørgsmålet om, hvorfor historiske tekster stadig betyder noget, og hvordan de taler til os nu", efterlades ubesvaret. Forestillingen om fremmedartethed er, vil jeg hævde, også følsomt over for den affektive resonans, som tekster besidder, fordi den retter sig mod deres forundrings- og fascinationskraft og dens historiske foranderlighed. Og den kan, endelig, nedtone den konflikt mellem opmærksomheden på den litterære teksts litteraritet og opmærksomheden på tekstens kontekst, som jeg læste frem af Felskis og Jays essays, idet den kontekstuelle undersøgelse dirigeres af tekstens fremmedartethed, der for læseren nødvendigvis må fremstå som specifik. Den største fordel ved Skinners forestilling om historiens fremmedartethed i forhold til litteraturhistoriske studier er for mig at se dog, at den tilskynder til at stille spørgsmål i stedet for at søge efter svar, som vi på forhånd kender.

\section{MOTIV OG KONTEKST}

Artiklens tese er som nævnt $\mathrm{i}$ indledningen, at det snarere er ved at tage udgangspunkt i den litterære teksts motiver end i dens temaer, at kontekstualiseringen af teksten kan italesætte dens historiske fremmedartethed. Det skyldes dels, at motivet optræder som en mere lokal og mere specifik tekststørrelse end temaet. I artiklen "Motiv, tema og stof" (2003) henviser Rasmus Thorning Hansen til den skelnen mellem de to begreber, som Der Kommission für litteraturwissenschaftliche Motiv- und Themenforschung ved 
Akademie der Wissenschaften zu Göttingen opererer med: "[M]otivet er en langt mere konkret, anskuelig og fast størrelse end temaet, der kan betragtes som den bærende idé i et værk." (280) Man kan dog indvende, at temaet i en konventionel forståelse som denne kommer til at fremstå som passivt. Temaet er også en kreativ kraft, som Erik A. Nielsen påpeger (Nielsen 47). ${ }^{5}$

Motivet kan optræde som en konkret manifestation af temaet. I 3. udgave af The Routledge Dictionary of Literary Terms (2006) skriver Victor Sage om temaet, at det:

kommer indirekte til udtryk gennem nogle tilbagevendende begivenheder, billeder eller symboler. Vi begriber temaet ved at udlede det - det er billedernes og symbolernes rationale, ikke deres mængde. [...] Taler vi f.eks. om temaet "drukning" i Dickens' Our Mutual Friend, siger vi blot, at det er en roman, hvor folk gentagne gange drukner, eller hvor drukning hyppigt nævnes, mens temaet "kristen udfrielse" tilbyder os en forklaring på betydningen af drukning. Tilbagevendende lokale indslag betegnes bedre med termen motiv. (Sage 239. Forfatterens kursivering)

Eksemplet illustrerer endvidere forskellen mellem en kontekstualisering, der retter sig mod motivet (i dette tilfælde drukning), og en, der retter sig mod temaet (i dette tilfælde kristen udfrielse). Mens den første vil orientere sig imod f.eks. dødelighedsstatistikker i Victoriatidens London, vil den anden orientere sig imod kristendommens frelselære.

Det peger frem mod den anden årsag til, at motivet er et mere hensigtsmæssigt udgangspunkt end temaet for italesættelsen af den litterære teksts historiske fremmedartethed: nemlig den at motivet, som Jesper Gulddal skriver i Litterære pasregimer (2008), fungerer som et interface, "hvor litteraturen på særlig tæt og frugtbar vis interagerer med en materiel, institutionel eller diskursiv virkelighed." (19) Denne forståelse af motivet underbygger han i praksis, gennem analyser af, hvordan pasmotivet iscenesætter relationen mellem statsmagten og den enkelte borger i værker af Schnabel, Fielding, Sterne, Dickens og Stendhal. Gulddal hævder ikke, at

5 Nielsen definerer på den ene side temaet som "et kunstværks organisationsprincip og enhedsbærende kraft", hvilket vedrører værkets produktion, og på den anden som "dets betydningstotalitet", hvilket vedrører det færdige værk. (Nielsen 46. Forfatterens kursivering) 
motivet er det eneste element i den litterære tekst, hvor denne interaktion finder sted, men at det på "meget konkret vis henviser til en bestemt historisk virkelighed", og derfor "kommer til at tjene som udgangspunkt for det litterære værks fortolkende bearbejdelse og iscenesættelse" (19) af denne. Erik A. Nielsen hævder tilsyneladende noget lignende om temaet, når han skriver, at det "er det sted, hvor den organiske alliance mellem kunst og liv fremtræder tydeligst." (Nielsen 47) Formuleringen "den organiske alliance" indikerer imidlertid netop, at der er tale om en mere abstrakt relation end den, som motivet iscenesætter.

På nogle principielle punkter står Gulddals forståelse imidlertid i et spændingsfyldt forhold til den motiv- eller toposforståelse, som man møder i den tradition, der udgår fra Ernst Robert Curtius' Europäische Literatur und lateinisches Mittelalter (1948). Gulddal kritiserer i sin bog denne tradition. Han karakteriserer dens arbejder som "rene kataloger over bestemte motivers verdenslitteraturhistoriske forekomster" med alt for få overvejelser over "disse motivers historicitet og deres værkinterne funktionalitet" (16). Men han diskuterer ikke ellers, hvordan hans egen motivforståelse forholder sig til traditionens. Med henvisning til at motivet "netop [er] kendetegnet ved at være konkret og historisk specifikt" (18), afviser han at beskæftige sig med begrebet på et generelt teoretisk niveau, hvilket indebærer, at hans forståelse af det får et vist cirkelsluttende præg. Gulddal specificerer heller ikke, hvordan hans brug af motivbegrebet forholder sig til toposbegrebet, men anvender termerne synonymt, som det fremgår af hans karakteristik af Curtius-traditionen.

For det første er det vigtigt at præcisere, hvilken status det historiske har i Curtius' toposforståelse og forholde den til Gulddals forestilling om motivet som interface. Curtius tager udgangspunkt i den antikke retorik, hvor "topikken er lagerrummet" (Curtius, Europäische Literatur 89), det vil sige et repertoire af abstrakte argumentationsstrukturer, som kan anvendes som skabelon for at opnå de ønskede effekter forskellige steder i talen. Hans bog fokuserer på, hvordan denne retoriske tradition lever videre i form af topoi i den middelalderlige latinske litteratur og de efterfølgende nationallitteraturer. Men ikke alle topoi stammer fra retorikken, nogle er opstået i poesien: 
Til de poetiske topoi hører naturens skønhed i den videste forstand [...] og ønskedrømme og -tider: Elysium [...], det jordiske paradis, guldalderen. Det samme gør livets vitale principper: Kærlighed, venskab, flygtighed. Alle disse temaer drejer sig om fundamentale betingelser for eksistensen og er derfor tidsløse [...]. De genspejler rækkefølgen af åndsepoker. Men i alle poetiske topoi er udtrykkets stil historisk determineret. (92)

Hvordan kan de poetiske topoi på samme tid være "tidløse" i deres beskæftigelse med "fundamentale betingelser for eksistensen" og reflektere "rækkefølgen af åndsperioder"? Carsten Meiner og Frederik Tygstrup diskuterer i artiklen "Le défi de la topologie littéraire" (2007) spørgsmålet og foreslår, at man kan fortolke Curtius' forståelse af det poetiske topos som en "intermediær form mellem eksistentielle temaer og udtryksstil" (180). I et kontinuum af mulige relationer mellem de to komponenter aktualiserer et givent topos én. Mens dets tematik er tidløst, er det topossets stilistiske egenskaber, der reflekterer dets åndshistoriske tilhørsforhold.

For Curtius er dette tilhørsforhold altså medieret af topossets form, mens det for Gulddal er via dets indhold, at den historiske virkelighed trænger ind i værket. Denne forskel i synet på begrebets historiske forpligtelse fører i Curtius' tilfælde til en relativt eksklusiv toposforståelse, der primært orienterer sig mod litteraturhistorien. I dens katalogiserende tilbøjelighed har hans fremstilling af denne historie noget statisk eller trægt over sig. I Gulddals tilfælde fører synet til en mere inklusiv og dynamisk toposforståelse, der i højere grad orienterer sig mod kultur- og socialhistorien. Et problem ved denne nedtoning af topossets formmæssige aspekter kan imidlertid være, at man afskærer dets begrebshistoriske forbindelse til retorikken, hvilket kan indebære en fare for, at man opløser toposset som meningsfuld litteraturvidenskabelig kategori. Dets almene aspekt (jf. "almensted") er (også) betinget af en standardiseret, og derfor genkendelig form. Det betoner Curtius, når han i artiklen "Beiträge zur Topik der mittellateinischen Literatur" (1941) definerer topoi som "faste klichéer eller tanke- og udtryksskemaer." (Curtius, "Beiträge zur Topik" 1) En stor fordel ved topikken er, at den er et nyttigt redskab til en diakron litteraturhistorisk analyse. Men det fordrer genkendelighed. Hvis man opererer med et topos-begreb, der giver køb på denne genkendelighed, kan man også give køb på topikkens diakrone anvendelighed. 
At toposset for Curtius har et standardiseret præg, har imidlertid også simpelthen at gøre med den litteratur, som han beskæftiger sig med. Han er, som Meiner og Tygstrup påpeger, specialist i romansk litteratur før 1700: "Denne litteraturs topoi er ifølge ham relativt homogene, netop fordi litteraturen er mindre orienteret mod den 'reelle' verden end mod en særlig psykologisk, social og politisk idealitet." (Meiner og Tygstrup 181) Den udfordring ("defi"), som de retter mod topologien i dag, er "at skabe plads til den fysiske og historiske virkelighed inden for rammerne af topos-begrebet" (182), det vil sige et forehavende, der flugter præcist med Gulddals, men som han i modsætning til Meiner og Tygstrup ikke forholder til topologiforskningens traditioner. De finder et svar på denne udfordring i Erich Auerbachs essay "La Cour et la Ville" (1951). Auerbach analyserer i essayet tilsynekomsten af denne betegnelse - som Meiner og Tygstrup altså forstår som et topos - der i 1700-tallet begyndte at blive anvendt til at benævne et teaterpublikum, idet han afgrænser den fra beslægtede termer som "lecteurs", "spectateurs", "auditeurs", "assemblée" og "public". Mens "la cour" refererede til adelen omkring hoffet, henviste "la ville" til en "tynd skorpe af det bourgeoisie, der udgjorde det urbane publikum" (168). På trods af forskellen i social rang udgjorde de to grupper en "selvomsluttende, homogen gruppe" (179) med egne kulturelle normer og idealer. I sin analyse demonstrerer Auerbach, at det, der forenede dem, var fælles socioøkonomiske vilkår. Hofadelen var blevet frataget deres traditionelle militære funktioner og udgjorde ikke længere andet end kongens omgangskreds, ligesom den del af bourgeoisiet, der udgjorde "la ville", var blevet afskåret fra deres oprindelige økonomiske forpligtelser.

Auerbachs behandling af "la cour et la ville" både adskiller sig fra og har lighedstræk med Curtius' topologi:

På den ene side, og i modsætning til topoi hos Curtius, har "la cour" og "la ville" en temmelig præcis materiel og historisk forankring. På den anden side besidder la cour og la ville en betydning, der overskrider denne deres fysiske og geografiske realitet. Der er snarere tale om typiske realiteter, som koordinerer en serie af begivenheder, det vil sige urbane beretninger [...], fremstillinger af magtforhold og beskrivelser af følelser [...]. (Meiner og Tygstrup 183) 
Auerbach beskæftiger sig altså med toposset på en måde, der både betoner dets socio-historiske kontekst - det som Gulddal kalder dets interaktion med en "materiel, institutionel eller diskursiv virkelighed" - og dets standardiserede karakter. På samme tid orienterer hans tilgang sig synkront mod den litterære teksts forhold til konteksten, og diakront mod tekstens forhold til den litteraturhistoriske tradition. Dermed udgør den et vigtigt supplement til Gulddals forestilling om motivet som interface.

I lighed med Gulddal anvender jeg her i artiklen termen "motiv" i stedet for "topos". Særligt spørgsmålet om toposforskningens relation til den retoriske tradition kan adresseres med en kort refleksion over forholdet mellem de to termer. I Narrative as Theme. Studies in French Fiction (1992) skelner Gerald Prince således mellem begreberne tema, motiv og topos:

Et motiv er ikke et tema, men en mulig illustration af det; eller, udtrykt anderledes og mere præcist: et motiv er et element i en gruppe objekter, der karakteriserer et tema i dets udvikling. [...] Et topos - den forstandige tåbe, det alderstegne barn, almenstedet - er heller ikke et tema, men en stabil konfiguration af motiver. (4)

Motivet og toposset kan begge optræde som manifestationer af den litterære tekst tematik og begge indgå som elementer i dens handling og dens figurative repertoire, men som "en stabil konfiguration af motiver" rummer toposset et retorisk aspekt, der er fraværende i det individuelle motiv.

\section{BAKTERIEMOTIVET I DANSK LITTERATUR}

Disse overvejelser over den rolle, som motivet spiller i forholdet mellem den litterære tekst og dens kontekst, vil jeg i det følgende forholde til et enkelt motiv i dansk litteratur, nemlig bakterier. Det har, som nævnt i indledningen, hidtil levet et overset liv i kritikken, hvad man næppe kan undre sig over, både fordi bakterier er nemme at overse, og fordi deres rolle i litteraturhistorien er temmelig diminutiv. Udover de tre tilfælde, som jeg vil diskutere, er der imidlertid andre, som jeg af pladshensyn ikke vil komme ind på, f.eks. H.C. Andersens situationsbeskrivende kortprosatekst "Vanddraaben" (1847), Aage Hermann von Kohls på mange måder monstrøse trebinds-roman Mikrobernes Palads (1907) og aktuelle udgivelser som Theis Ørntofts Digte 2014 (2014), Nikolaj Zeuthens Nigeriabreve (2015) og Ida 
Marie Hedes Bedårende (2017). Af samme årsag vil jeg heller ikke inddrage den hastigt voksende litteratur om bakteriers kulturhistorie. Fokus for de korte motivlæsninger er på bakterier som modhager i teksternes forhold til deres kontekst.

\section{JOHANNES V. JENSEN: MADAME D'ORA}

Madame d'Ora (1904) er en af Johannes V. Jensens to såkaldte amerikaromaner. Den anden er Hjulet (1905), hvori handlingstråde og karakterer fra Madame d'Ora går igen, ligesom menneskets placering i evolutionsprocessen er en fælles, overordnet tematik for romanerne. De er vidnesbyrd om den fascinationskraft, som alverdens samtidsfænomener inklusive boksekampe, automobiler og naturvidenskabelige innovationer havde på Jensen, ligesom de demonstrerer hans forsøg på gennem skriften at komme på omgangshøjde med samtiden. Bo Hakon Jørgensen karakteriserer således Madame d'Ora som "et bad i tiden omkring 1900" (Jørgensen).

Handlingen i romanen koncentrerer sig om den celebre videnskabsmand Stuart Hall, opdageren af grundstoffet radium, der også har en stærk spiritistisk interesse. Hans laboratorium på tolvte sal på Manhattan er scene for videnskabeligt efterprøvede seancer. De overværes blandt andet af titelfiguren, sangerinden Leontine d'Ora, der er Halls gamle flamme fra Europa. Det viser sig senere, at seancerne er et svindelnummer, der er blevet iscenesat af prædikanten Evanston med det formål at udnytte Halls opdagelse af radium økonomisk. Snyderiet afsløres af en tilskuer, der, da Evanston under en af seancerne træder frem for tilskuerne som the missing link i evolutionshistorien, udbryder: "Denne Aand har et falskt Skæg!" (Jensen 162) I slutningen af romanen begår Hall medlidenhedsdrab på Madame d'Ora og bliver fængslet.

Bakterier optræder i romanen som et Tjekhovs gevær, der hænger på væggen og senere affyres. I romanens første halvdel fremviser Hall sin samling af "baciller" for Madame d'Ora og Evanston. Et af reagensglassene indeholder "Spirer til Hydrofobi, [...] Hundegalskab, nok til at smitte en hel Provins" (47). Under den tumult, der opstår i forbindelse med afsløringen af Evanstons svindelnummer, bliver Madame d'Ora stukket med skår fra reagensglasset. Hall kører hende ud på Long Island, hvor hun straks be- 
gynder at vise en hundelignende adfærd. Fremstillingen af inficeringen accentuerer, at den er umiddelbar og konkret. Madame d'Ora lægger sig ned på alle fire:

Hun trak Hovedet ned imellem Armene, stirrede på Edmund:

Vuf! Gøede hun. Vuf!

Leontine, kom dog her!

Hun gjorde et sæt baglæns:

Vuf! Va, va! Hrrr ...

Hun trak sig nærmere:

Rrrrr ...

Leontine!

Da strakte hun Struben, og idet hele hendes Ansigt blev lighvidt, brød hun ud i en jammerfuld Tuden, der snart blev mere vild, hun kastede sig omkring og løb et Stykke bort, rystede Hovedet og blev staaende stiv paa alle fire.

A-aa! Huh! Aa-huh!

Hun fik Øje på Automobilet og løb ind paa et af Hjulene, slog sine Tænder i Gummiringen og ruskede deri, saa hele Vognen dirrede, blev hængende derved, knurrende. (183-184)

Bakteriemotivet i romanen optræder som et centralt element i det spændingsfelt mellem det videnskabelige og det overnaturlige, som er brændpunktet i Madame d'Ora, og som relaterer romanen til en række samtidige værker som Bram Stokers Dracula (1897) og August Strindbergs Inferno (1898). Helt konkret var Jensens model for Hall den britiske kemiker William Crookes, der på samme tid var medlem af Storbritanniens videnskabsakademi Royal Society og præsident for det spiritistiske Society of Psychical Research (Barz 128-129). Nok afsløres de spiritistiske seancer, der finder sted i Halls laboratorium, som svindel, men mistroen retter sig i lige så høj grad imod den videnskab, som Hall repræsenterer, der på trods af al dens tekniske kunnen lader sig forføre af så simple virkemidler som mangelfuld belysning, faldlemmer og falsk skæg. Men læserne af romanen efterlades faktisk også helt eksplicit med det, som Tzvetan Todorov benævner som en "fantastisk tøven" (Todorov). Det insinueres, at Hall tidligere på Jack the Ripper-vis har dræbt en arbejderske i London, og denne unge kvinde viser sig - muligvis - under en af seancerne. Er de da overhovedet svindel?

Den videnskabelige supernaturalisme, man møder i Madame d'Ora, er et vidnesbyrd om, at den "affortryllelse" af verden, som den tyske sociolog 
Max Weber forbinder med moderniteten (Weber), absolut ikke er utvetydig. Som et vigtigt bidrag til medicinens videnskabelige udvikling kan man på den ene side hævde, at bakteriologien bidrog til denne affortryllelse: Sygdomsfremkaldende agenter til f.eks. hundegalskab kunne nu identificeres og isoleres i reagensglas og blev dermed håndgribelige. Men samtidig demonstrerer hundescenen på Long Island, at man tillagde bakterierne en transformerende kraft, der bedst kan beskrives som magisk.

\section{VILLY SØRENSEN: BLOT EN DRENGESTREG}

Handlingsforløbet i "Blot en drengestreg", der udkom i Villy Sørensens første novellesamling Sære fortællinger (1953), er præget af stærke kausale forbindelser. Et element leder med en bogstavelig logik frem mod det næste, samtidig med at situationen udvikler sig mere og mere kaotisk. Den mest åbenlyse grund til, at novellen er sær, jævnfør samlingens titel, er det voldsomme sammenstød mellem på den ene side forløbets ensporede enkelhed og den tilforladelige sprogbrug, der kombinerer det højtideligt-arkadiske og pudsigt-infantile, og på den anden side den væmmelsesfremkaldende interesse for kroppens sårbarhed og for den teatralske iscenesættelse af dens ødelæggelse, som novellen demonstrerer: "Og storebror savede mens blodet sprøjtede og trævler og kød væltede op i savrenden der ikke blev så lige som den helst skulle." (Sørensen 38) Som Per Stounbjerg bemærker, er der en voldsom proportionsforvrængning i storebrorens fokusering på sine saveegenskaber (Stounbjerg 59). Effekten er mildt sagt desorienterende.

Jeg vil her fokusere på novellens slutning. Da brødrenes offer ligger livløs, og hele køkkenet er blevet smurt ind i blod, begynder de at frygte deres mors reaktion. De lægger drengen ud på vejen og begynder at vaske køkkenet, men med det resultat, at blodet bliver tværet endnu mere rundt. Politiet ankommer, og så endelig moren, der over for politiet insisterer på at gøre dem rene, og hun "vaskede dem hvide som engle", som det hedder i novellens afsluttende slutning (Sørensen 41). Jon Helt Haarder problematiserer med henvisning til novellens voldsomme virkemidler, at "Blot en drengestreg" har nogen etisk dimension: "Villy' [Haarder skelner mellem forfatteren 'Villy' og filosoffen og formidleren 'Sørensen'] har brugt fire 
sider på en scene, hvor en lille dreng parteres af to andre, mens fortælleren river vitser af." (Haarder 5) Jeg kan sagtens følge ræsonnementet, men Haarder har nu ikke helt ret. Novellen anvender cirka to sider på beskrivelsen af parteringen og andre to på fremstillingen af brødrenes gryende forståelse af, at de ikke vil blive belønnet, men straffet af omverdenen - især moren - og af deres forgæves forsøg på at gøre rent efter den.

Det er denne hygiejniske bestræbelse i novellen og dens kontekst, som jeg mener bakteriemotivet peger på. Hvis man fokuserer på den og ikke på parteringen, mener jeg faktisk, at novellen formulerer en klar samfundsmæssig kritik og dermed en etisk position. Både brødrenes forsøg på at stoppe bakteriernes vandring op igennem drengens ben, deres forsøg på at vaske sporene efter deres handling bort, og morens rensning af dem, kan forstås i lyset af den socialhygiejniske bevægelse i det 19. og 20. århundrede. Den har Lars-Henrik Schmidt og Jens Erik Kristensen i dansk sammenhæng analyseret i Lys, luft og renlighed. Den moderne social-hygiejnes fødsel (1986). Socialhygiejnens opståen er betinget af bakteriologien og af de nye forestillinger om renhed og urenhed, som den affødte.

I den ene ende af det spektrum, som socialhygiejne som begreb refererer til, finder man bestræbelsen på at forbedre befolkningens levevilkår via blandt andet bedre boliger og en indførsel af bedre hygiejniske standarder i hjemmet. Som Schmidt og Kristensen gør rede for, var husmoren det primære instrument for denne bestræbelse (115-130). Her er en direkte forbindelse til morens rolle i "Blot en drengestreg". Brødrenes ageren i slutningen af novellen er i lige så høj grad betinget af bevidstheden om deres overtrædelse af disse hygiejniske standarder som af bevidstheden om deres overtrædelse af Dekalogens femte bud: "Sæføli kan han da ikke blive levende igen når han er død af blodforgiftning. Se nu hvordan her ser ud." (Sørensen 39) I den anden ende af det spektrum, som socialhygiejne refererer til, finder man eugenikken, altså forestillinger om, hvordan man kan forbedre befolkningens genetiske materiale, der som bekendt kulminerede i nazisternes udryddelseslejre. Også her er der en forbindelse til Sørensens novelle. Dens udgivelsestidspunkt taget i betragtning, er det vanskeligt at forestille sig, at den udmalede beskrivelse af brødrenes forsøg på at save drengens ben over, og novellens implicitte pointering af, at mennesket ikke har en medfødt moral, der adskiller os fra dyrene, og som beskytter 
os mod hinanden, ikke fremmanede vidnesbyrd om nazisternes aktiviteter hos sam-tidige læsere.

I "Blot en drengestreg" forbinder Villy Sørensen de to poler i den socialhygiejniske bevægelse, der som nævnt er betinget af bakteriologien. Novellen er en gravskrift over denne bevægelse. Den indtager i den en - som jeg ser det - klar etisk position, der afviser hygiejneforestillinger som noget, man kan bygge samfund på.

\section{BJØRN RASMUSSEN: HUDEN ER DET ELASTISKE HYLSTER DER OMGIVER HELE LEGEMET}

I Bjørn Rasmussens prosadebut, romanen Huden er det elastiske hylster der omgiver hele legemet (2011), vokser hovedpersonen Bjørn op blandt heste et sted i Jylland, ligesom forfatteren selv gjorde det. Bjørn har, fra han er 15 år, et på alle måder grænseoverskridende, sadomasochistisk forhold til sin mandlige ridelærer. Som 18-årig flytter han til København, hvor han igen møder ridelæreren. I midten af romanen finder man tre, tilsyneladende private fotografier, der udgør en spejlingsakse i den. De to halvdele på hver side af aksen fortæller nogenlunde den samme historie, men der er også markante forskelle på dem. I den ene del ernærer Bjørn sig som superprostitueret på et bordel i København, mens han i den anden bliver sekretær for en transseksuel sangerinde. I den ene del genoptager Bjørn og ridelæreren parforholdet og bosætter sig sammen i landlig idyl, i den anden del gør de det ikke.

Rasmussens roman er udtryk for en biologisk bevågenhed i samtidslitteraturen, der orienterer sig mod kroppens materialitet, og særligt mod denne materialitets opløsning:

Det var hestene. De var gået i forrådnelse. De stod helt stille og faldt fra hinanden. Et stort stykke kød løsnede sig fra skulderbladet og faldt ned i den stride, gule halm. Et langt sår i lysken sprak, og hele bagpartiet gik i stykker, lårene, halen, rygsøjlen smuldrede som rugmel. Et øje faldt ud af sin hule og hang i slimede strenge, dinglede et øjeblik mod den væskende mule, inden den sidste streng bristede, og øjet faldt mod jorden. (Rasmussen 26)

Julia Kristevas begreb om det abjekte er, som Lillian Munk Rösing har demonstreret i en læsning af Huden er det elastiske hylster der omgiver hele le- 
104 KULTUR \& KLASSE * $123 * 2017$

TOPOLOGI

gemet, relevant i forhold til romanen (Rösing 44-48). Abjektet betegner det, som hverken er subjekt eller objekt, f.eks. forskellige former for kropsligt affald såsom blod, pus, ekskrementer, urin, sved og spyt. Hvad der kendetegner disse kropslige materialer, er både, at det er noget, kroppen fortsat må udstøde for at opretholde sig selv, og at det er noget, der opfattes som væmmeligt. Noget af det, der karakteriserer romanen er, at den i en ekstrem grad holder sig åben over for det abjekte - og det gør læseoplevelsen væmmelig.

Fokuseringen på kroppens opløsning og åbenhed indgår i, hvad jeg opfatter som det primære ærinde i romanen, nemlig at skrive sig uden-, bag- og nedenom overleverede subjektpositioner i en bestræbelse på at etablere nogle nye og mere rummelige. Disse nye positioner findes ikke før skriften, men i og med den. Dermed bliver sproget i Rasmussens roman handlende på en måde, der kan sammenlignes med klassiske eksempler på talehandlinger, udtalt inden for de rette sociale rammer.

Bakterier optræder i romanen i en enkelt sætning, der gentages nogle gange i let varierende former: "[J]eg er et sætstykke af organer. [...] Jeg kan undvære tyktarmen, jeg skal bare have en pose på maven til at samle væskerne, jeg er selv en pose med bakterier, intet andet. Og milten kan jeg undvære, én af lungerne og én af nyrerne og 4/5 af den rødbrune lever" (Rasmussen 18-19). I passagen ligger der en klar nedskrivning af mennesket, en reduktion af det på kropsmaterialistiske vilkår. Alle udsagnene udtrykker hvad jeg'et kan leve foruden, med undtagelse af "jeg er selv en pose med bakterier, intet andet", som udtrykker noget, der er. I den forstand er dette udsagn positivt. Det udgør nedskrivningens nulpunkt og endestation ("intet andet").

På trods af reduktionen af jeg'et kan udsagnet imidlertid også forstås som et udgangspunkt for en ny subjektposition, der i bogstavelig forstand er åben. Ifølge mikrobiologen Justin Sonnenburg er der for hver menneskelig celle ti bakterier på kroppen. Han mener derfor at vi burde begynde at opfatte vores legeme som "en kompliceret beholder, der er optimeret for væksten og udbredelsen af vores mikrobiologiske indbyggere." (Pollan) I forlængelse af Sonnenburgs opfordring kan Rasmussens udsagn perspektiveres til den såkaldte symbiogenese, en teori, der inden for biologien igennem de seneste 40 år har vundet udbredelse (Marsalis og Sagan). Ifølge den er det princip, der ligger til grund for livets opretholdelse og udvikling, 
ikke "the survival of the fittest" (som det er tilfældet i Madame d'Ora), men en kreativ interaktion mellem organismer, som f.eks. mennesker og bakterier, der gensidigt styrker hinanden. At være "en pose af bakterier, intet andet" indebærer således et opgør med et antropocentrisk verdensbillede, ligesom det indebærer en ny etik, der forpligter subjektet på dets forhold til omverdenen.

\section{KONKLUSION}

I alle tre tekster iscenesætter motivet et møde mellem bakterier (eller forestillinger om bakterier hos Sørensen) og menneskekroppe, og i alle tre tilskrives bakterier en form for agens. Det er de to tilbagevendende elementer i motivet. Bakteriernes virkning fremstilles mest eksplicit, men også mest afgrænset hos Jensen, hvor de med en transsubstantierende kraft forvandler Madame d'Ora til hund, og mest implicit, men også mest omfattende hos Rasmussen, hvor de er anledning til formuleringen af en ny subjektposition på kropslige betingelser. Sørensens tekst placerer sig mellem disse to yderpunkter. Her optræder bakteriemotivet både som igangsættende faktor af det på samme tid enkle og kaotiske handlingsforløb, og som en mental forestilling der ligger til grund for den hygiejniske fiksering, som novellen italesætter og kritiserer.

Fælles for bakteriemotivet i de tre tekster er også, at de optræder som komponenter i topoi (Prince): et laboratorie-topos hos Jensen, et hjem-topos hos Sørensen og et krop-topos hos Rasmussen. Denne bevægelse fra det ydre mod det indre udtrykker en udvikling i teksternes fremstilling af bakterier: som letale patogener, der som videnskabelige objekter kan isoleres i reagensglas hos Jensen, som allestedsnærværende patogener, som vi må iværksætte et omfattende hygiejnisk regime for at holde bort hos Sørensen, og som "mikrobiologiske indbyggere" i den menneskelige krop hos Rasmussen, hvis tilstedeværelse betinger vores forestillinger om os selv og vores forhold til omverdenen. De tilbagevendende elementer i bakteriemotivet befordrer således en diakron opmærksomhed på teksternes indbyrdes forhold.

Samtidig befordrer motivet som "interface" til "en materiel, institutionel eller diskursiv virkelighed" (Gulddal 19) en synkron opmærksomhed 
på teksternes forhold til deres kontekst. Hos Jensen peger bakteriemotivet på naturvidenskabernes status omkring år 1900 og deres forhold til den samtidige, massive interesse for okkultisme, spiritisme og esoterisme som kontekst, hos Sørensen peger motivet mod socialhygiejnens samfundsmæssige konsekvenser som kontekst og hos Rasmussen mod forholdet mellem kroppen og subjektiviteten som kontekst for teksten. Disse kontekster er ikke de eneste, der er relevante for forståelsen af de tre tekster, men de er alle væsentlige, og bakteriemotivets udpegning af dem er i alle tre tilfælde særdeles præcis. Konteksterne er historisk specifikke (Skinner). De er karakteristiske for de tre teksters udgivelsestidspunkter, hvilket jeg har forsøgt at demonstrere med nogle få kulturhistoriske referencer i analyserne. Denne specificitet betinger de tre teksters historiske fremmedartethed, der naturligt nok er tiltagende med afstanden i tid.

Jens Lohfert Jørgensen, lektor i dansk litteratur på Aalborg Universitet. Forfatter til bogen Sygdomstegn. En symptomatologisk læsning af J.P. Jacobsens Niels Lyhne (Syddansk Universitetsforlag 2014) og en række artikler om litteraturhistoriografi, bakteriologisk modernisme, litteratur og medicin og om J.P. Jacobsen, August Strindberg, Joris-Karl Huysmans, Helga Johansen, George Orwell, Anders Bodelsen, Morten Søndergaard og Joseph Conrad.

\section{MOTIVE AND CONTEXT}

This article deals with the properties and functions of the literary motif in relation to the text's context. One tendency in present-day literary historiography is a growing scepticism towards contextualism. It takes its point of departure in a wish, on the critic's part, to engage more actively with the text than a focus on its contexts allows. In the first part of the article, I present two concrete instances of this scepticism. In opposition to it, I defend contextualism - in the specific form of a historiographical practice that is able not only to make literary works more comprehensible to us, but also to make them more strange. I discuss Quentin Skinner's formulation of this idea in the article's second part. The article's main thesis is that is by focusing on motifs, rather than themes, that we can verbalize the historical strangeness of literature. In the third part of the article, I discuss the motif's 
ability to relate to the text's context, drawing on the work done of Jesper Gulddal, Ernst Robert Curtius and Erich Auerbach. In the article's fourth part, I relate my reflections on the relation between motif and context to the motif of bacteria in Danish literature. In three short readings of texts by Johannes V. Jensen, Villy Sørensen and Bjørn Rasmussen, I demonstrate how a focus on the motif at the same time promotes a synchronic perspective on the texts' relation to their contexts, and a diachronic perspective on their mutual similarities and differences.

\section{KEYWORDS}

DA: Litteraturhistoriografi, Kontekst-begrebet, Quentin Skinner, Det litterære motiv, Bakteriemotivet i dansk litteratur, Johannes V. Jensen, Villy Sørensen, Bjørn Rasmussen

EN: Literary historiography, context as concept; Quentin Skinner; literary motif; bacteria as motif in Danish literature; Johannes V. Jensen, Villy Sørensen, Bjørn Rasmussen

\section{LITTERATUR}

Auerbach, Erich. "La Cour et la Ville". Scenes from the Drama of European Literature. Minneapolis: University of Minnesota Press, 1984. 133-179 (1951).

Barz, Christiane. "Scientific Spirit, Spirituality and Spirited Writing. Spiritualism between science, religion and literature." TijdSchrift voor Skandinavistiek 311 (2010): 121-158.

Beck-Lassen, Franz. "Afselvfølgeliggørelse - Idéhistorien raison d'être". Slagmark 67 (2013): 13-27.

Curtius, Ernst Robert. "Beiträge zur Topik der mittellateinischen Literatur." Corona Querna. Festgabe Karl Strecker zum 80. Geburtstages dargebracht. Leipzig: Hiersemann, 1941. 1-14.

Curtius, Ernst Robert. Europäische Literatur und lateinisches Mittelalter. Bern/München: Francke Verlag, 1973 (1948).

Dimock, Way Chee. "A Theory of Resonance". PMLA 1125 (1997): 1061-1071. doi: 10.2307/ 463483

Felski, Rita. "Context stinks!" New Literary History 424 (2011): 573-591.

Gulddal, Jesper. Litterære pasregimer. Bevægelseskontrol og identifikation i europæisk litteratur 1725-1875. København: Museum Tusculanums Forlag, 2008.

Hansen, Rasmus Thorning. "Motiv, tema og stof". Om litteratur-metoder og perspektiver. Red. Leif Sønder-gaard. Århus: Systime, 2003. 268-92.

Haarder, Jon Helt. "Villy og Sørensen. Skitse til en genlæsning af et forfatterskab." Kritik 143 (2000): 1-9. 
Jay, Martin. "Historical Explanation and the Event: Reflections on the limits of Contextualization." New Literary History 424 (2011): 557-571.

Jensen, Johannes V. Madame d'Ora. København: Gyldendal, 1916 (1904).

Jørgensen, Bo Hakon. "Den amerikanske modernitet oversat til dansk." Kristelig Dagblad 20. september 2011.

Marsalis, Lynn og Dorion Sagan. Acquiring Genomes. A Theory of the Origin of Species. New York: Basic Books, 2002.

Meiner, Carsten og Frederik Tygstrup. "Le défi de la topologie littéraire". Revue Romane 422 (2007): 177-187.

Nielsen, Erik A. "Tema". Om litteraturanalyse. Red. Lis Møller. Århus: Systime, 1995. 45-75.

Perkins, David. "Historical Contextualism". Is Literary History Possible? Baltimore/London: The Johns Hopkins University Press, 1992. 121-52.

Pollan, Michael. "Some of My Best Friends are Germs." New York Times Magazine 19.5.2013.

Prince, Gerald. Narrative as Theme. Studies in French Fiction. Lincoln: University of Nebraska Press, 1992.

Rasmussen, Bjørn. Huden er det elastiske hylster der omgiver hele legemet. København: Gyldendal, 2011.

Rösing, Lillian Munk. "Når kroppen flyder. Om kropsvæsker i aktuel dansk litteratur." Kritik 209 (2013): 44-50.

Sage, Victor. "Theme". The Routledge Dictionary of Literary Terms. Red. Peter Childs og Roger Fowler. 3. udg. London/New York: Routledge, 2006. 239-40.

Schmidt, Lars-Henrik og Jens Erik Kristensen. Lys, luft og renlighed. Den moderne socialhygiejnes fødsel. København: Akademisk Forlag, 1986.

Sestoft, Carsten. "Tekst og kontekst i litteraturhistorien. Litteratur som distinkt historisk praksis." K\&K 292 (2001): 109-22.

Skinner, Quentin. "Frihedsbegrebet og historikeren." Politik og historie. En tekstsamling. Red. Frank Beck-Lassen og Mikkel Thorup. København: Hans Reitzels Forlag, 2009. 241-253 (1998).

Skinner, Quentin. "Mening og forståelse i idéhistorien." Politik og historie. En tekstsamling. Red. Frank Beck-Lassen og Mikkel Thorup. København: Hans Reitzels Forlag, 2009. 47-95 (2002).

Skinner, Quentin. "Interpretation and the understanding of speech acts." Visions of Politics vol. 1. Regarding Method. Cambridge: Cambridge University Press, 2002. 103-27.

Skinner, Quentin. "Quentin Skinner on Meaning and Method." the art of theory. conversations in political philosophy. 2011. Web. 30. September 2016. http://www.artoftheory. com/quentin-skinner-on-meaning-and-method/.

Stounbjerg, Per. "Om det banale og fatale i 'Blot en drengestreg'". Både frem og tilbage. Portræt af Villy Sørensens forfatterskab. Red. Marianne Barlyng og Jørgen Bonde Jensen. Hellerup: Spring, 2002. 59-66.

Sørensen, Villy. "Blot en drengestreg". Sære historier. København: Gyldendal, 1963 (1953).

Todorov, Tzvetan. Den fantastiske litteratur. En indføring. Århus: Klim, 2007 (1971).

Tucker, Herbert F. "Introduction." New Literary History 424 (2011): vii-xii.

Weber, Max. Wissenschaft als Beruf. Stuttgart: Reclam, 1995 (1919). 